\title{
Úr gögnum Hjartaverndar: \\ Faraldsfræði kransæðasjúkdóma á Íslandi í hálfa öld
}

\author{
Karl Andersen læknir ${ }^{1,2,3}$, Thor Aspelund tölfræðingur ${ }^{1,2}$, Elías Freyr Guðmundsson faraldsfræðingur ${ }^{1}$, \\ Kristín Siggeirsdóttir iðjupjálfi'1,4, Rósa Björk Pórólfsdóttir læknir ${ }^{2}$, Gunnar Sigurðsson læknir ${ }^{1,2}$, \\ Vilmundur Guð̃nason læknir ${ }^{1,2}$
}

\section{A G R I P}

Kransæðasjúkdómar hafa verið algengasta dánarorsök Íslendinga frá miðri síðustu öld allt fram undir síđasta áratug. Frá 1980 hefur stađa helstu áhættupátta kransæðasjúkdóma farið sífellt batnandi og hefur sú próun skýrt $72 \%$ peirrar fækkunar sem orðið hefur í ótímabærum dauð̌sföllum vegna kransæðasjúkdóma á síðustu premur áratugum. Hins vegar hafa vaxandi offita og sykursýki dregið nokkuð úr peim ávinningi. Verði ekkert að gert má búast við pví að dauðsföllum vegna kransæðasjúkdóma fari aftur fjölgandi á næstu áratugum. Kemur par annars vegar til breytt staða helstu áhættupátta og hins vegar vaxandi öldrun pjóðarinnar. Á sama tíma hefur lifun eftir hjartaáfall aukist. Afleiðingin verður ekki eingöngu sú að öldruðum fjölgar og peir verða sífellt stærra hlutfall pjóðarinnar, heldur koma aldraðir til með að lifa með aukna byrði langvinnra sjúkdóma á næstu áratugum. Petta mun hafa í för með sér verulega aukinn kostnað í heilbrigðiskerfinu. Út frá mannfjöldaspá Hagstofunnar má áætla að̃ fjöldi Íslendinga á vinnufærum aldri (16-66 ára) fyrir hvern ellilífeyrispega (67 ára og eldri) muni lækka úr 5,6 árið 2016 i 3,3 árið 2040 og i 2,6 árið 2060. Í pessari grein veður fjallað nánar um áhrifapætti pessarar próunar og staða áhættupátta kynnt með uppfærðum tölum fram til ársins 2013

\section{Inngangur}

Á undanförnum áratugum hefur orðið mikil breyting í nýgengi kransæðasjúkdóma á Íslandi. Um og upp úr miðri síðustu öld varð stöðug aukning í sjúkdómnum allt fram undir 1980. Síðan pá hefur verið stöðug lækkun í nýgengi sem endurspeglast í samsvarandi fækkun dauðsfalla vegna kransæðasjúkdóma á Íslandi.

Pessi jákvæða próun síðustu áratuga skýrist að mestu leyti af breyttum lífsstíl og æskilegum áhrifum hans á áhættupætti kransæðasjúkdóma en einnig af framförum í læknisfræðilegri meðferð. ${ }^{1}$ Par eru pó blikur á lofti. Áhættupættir sem skýrðu verulegan hluta kransæðasjúkdóma á síðustu öld, eins og reykingar, hátt kólesteról í blóði og háprýstingur, hafa verið á undanhaldi. Í staðinn eru til komnir aðrir áhættupættir eins og offita og sykursýki, sem fara stöðugt vaxandi. Allt bendir til pess að pessir nýju áhættupættir muni á næstu áratugum snúa við hinni jákvæðu próun og að nýgengi kransæðasjúkdóma fari vaxandi á ný. ${ }^{2}$

Horfur peirra sem fá kransæðastíflu hafa batnað mikið á undanförnum áratugum, meðal annars vegna tæknilegra framfara og bættrar lyfjameðferðar. ${ }^{3}$ Um miðja síðustu öld dó priðji hver sjúklingur með kransæðastíflu áður en hann náði að útskrifast af sjúkrahúsi en í dag er 30 daga dánarhlutfallið um $6 \%$, sem er sambærilegt pví sem best gerist í heiminum. ${ }^{4-5}$ Petta hefur ásamt öðru átt stóran pví að hjartasjúklingar lifa lengur með kransæðasjúkdóminn en áður og stuðlar pað að auknu langlífi pjóðarinn-

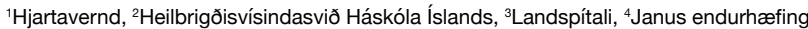

Fyrirspurnum svarar Karl Andersen andersen@landspitali.is

https://doi.org/10.17992/lbl.2017.10.153

Greinin barst blađinu 17. júní 2017, sambykkt til birtingar 13. september 2017. ar. Mikilvægt er að átta sig á pví að lækkandi nýgengi og bætt meðferð hefur ekki útrýmt sjúkdómnum heldur verða afleiðingar hans síðar á ævinni. Pannig munu tveir priðju hlutar peirra sem fá hjartaáfall eldri en 70 ára lifa hjartaáfallið af og allt að $40 \%$ peirra próa með sér hjartabilun (óbirtar niðurstöður í Öldrunarrannsókn Hjartaverndar). Sömuleiðis má gera ráð fyrir að $75 \%$ aldraðra sem fá heilablóðfall verði lifandi eftir eitt ár og um $40 \%$ lifandi að minnsta kosti premur árum eftir áfallið (óbirt úr rannsóknum Hjartaverndar).

Í pessari yfirlitsgrein er fjallað um pær breytingar sem hafa orðið á áhættupáttum og horfum kransæðasjúkdóma á Íslandi allt fram til ársins 2013. Rannsóknir Hjartaverndar benda til pess að breytingar á lífsstíl pjóðarinnar muni leiða af sér vaxandi dánartíðni vegna sjúkdómsins á komandi áratugum. Hjartaáföll munu færast á eldri aldurshópa og sífellt stærra hlutfall peirra sem fá kransæðastíflu lifa fram á efri ár með langvinnum afleiðingum sjúkdómsins. ${ }^{6}$

\section{Efniviður}

Í gögnum Hjartaverndar má finna faraldsfræðilegar upplýsingar um áhættupætti íslensku pjóðarinnar síðustu fimm áratugina. Yfirlit um pær rannsóknir sem liggja til grundvallar pessu gagnasafni má finna í töflu I.

Rannsóknabýðin eru fimm. Í fyrsta lagi Reykjavíkurrannsókn Hjartaverndar sem stóð frá stofnun Rannsóknarstofunnar 1967 til 2001. ${ }^{7-9}$ Öllum körlum og konum sem bjuggu á stór-Reykjavíkursvæðinu og voru fædd 1907-1935 var boðið að koma til skoðunar og var pað almennt pýði um 55\% Íslendinga á pessu aldursskeiði á peim tíma. Hlutfall peirra sem komu til skoðunar var rúmlega 70\%, eða nálægt 19 púsund manns. Árið 2002 var byrjað á Öldr- 
Tafla I. Fjöldi einstaklinga á aldrinum 50-69 ára, eftir tímabili og rannsókn.

\begin{tabular}{|c|c|c|c|c|c|c|c|c|c|c|c|}
\hline Tímabil & 1967-'69 & $1970-' 74$ & 1974-'79 & $1979-' 86$ & 1985-'91 & 1993-'94 & 1997-'03 & 2004-'08 & 2008-'10 & 2011-'13 & \\
\hline Miðgildisár tímabils & 1968 & 1971 & 1977 & 1983 & 1988 & 1993 & 2000 & 2006 & 2009 & 2012 & Samtals \\
\hline Reykjavíkurrannsóknin & 1655 & 2421 & 3019 & 2304 & 1902 & & & & & & 11301 \\
\hline Monica 1983 & & & & 910 & & & & & & & 910 \\
\hline Monica 1988 & & & & & 912 & & & & & & 912 \\
\hline Monica 1993 & & & & & & 958 & & & & & 958 \\
\hline Ungir & & & & & & & 1897 & & & & 1897 \\
\hline Öldrunarrannsóknin (AGES) & & & & & & & & 238 & & & 238 \\
\hline REFINE - fyrri koma & & & & & & & & 1555 & 1811 & 137 & 3503 \\
\hline REFINE - seinni koma & & & & & & & & & 348 & 1610 & 1958 \\
\hline Samtals & 1655 & 2421 & 3019 & 3214 & 2814 & 958 & 1897 & 1793 & 2159 & 1747 & 21677 \\
\hline
\end{tabular}

unarransókninni, sem unnin var í samvinnu við National Institute of Aging (NIA) í Bandaríkjunum og stóð sú rannsókn til ársins 2011. ${ }^{10}$ Í Öldrunarrannsókninni voru rannsakaðir tæplega 6000 einstaklingar sem voru á lífi á peim tíma og tekið höfðu pátt í Reykjavíkurrannsókninni. Monica-rannsóknin var stöðluð gagnaskráning sem unnin var í samvinnu við Alpjóðaheilbrigðismálastofnunina (WHO) á tímabilinu 1981 til 1994. Hún náði til allra tilfella af kransæðastíflu á landinu hjá einstaklingum milli 25 og 74 ára og var um leið áhættupáttakönnun. Refine-rannsóknin var slembiúrtak 9480 einstaklinga á Reykjavíkursvæðinu sem voru fæddir 1935-1985 og var pátttökuhlutfall 73\%.11 Rannsóknin var unnin á tímabilinu 2006-2012. Í öllum pessum rannsóknum voru pátttakendur skoðaðir og hefðbundir áhættupættir mældir á staðlaðan hátt. Blóðmælingar voru gerðar fastandi.

Tafla 1 sýnir fjölda einstaklinga á aldursbilinu 50-69 ára úr ofangreindum rannsóknum en pað aldursbil er notað par sem flestir einstaklingar eru á pví aldursbili og lægst vikmörk. Um er að ræða umfangsmikið safn upplýsinga rúmlega 21 púsund karla og kvenna sem endurspeglar áhættupætti og líffræðilegar mælingar heillar pjóðar. Pessar upplýsingar ásamt upplýsingum um hjartasjúkdóma og dauðsföll úr dánarmeinaskrá liggja til grundvallar gagnasafni Hjartaverndar sem er í raun einstakt á heimsvísu.

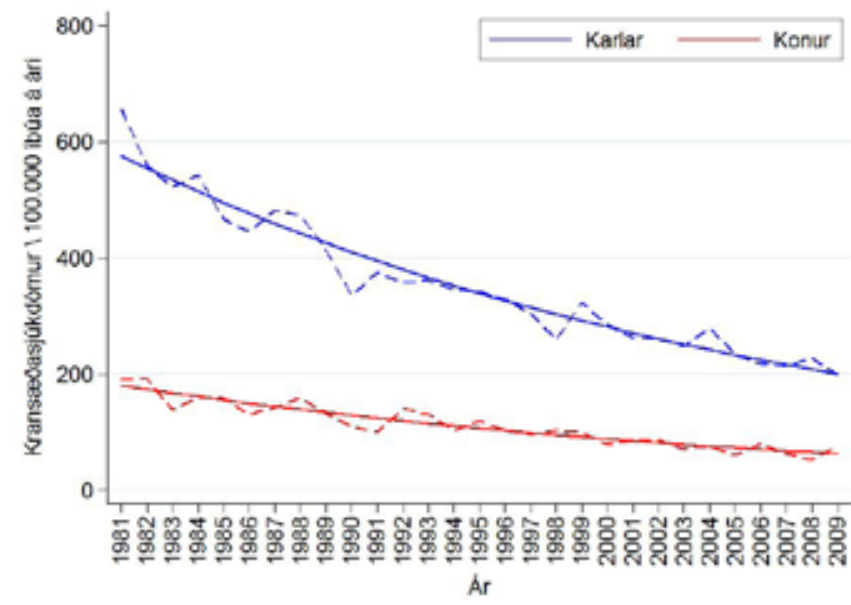

Mynd 1a. Aldursstaðlað nýgengi kransæðasjúkdóma samkvæmt aldurssamsetningu 2009 .
Hér birtast uppfærðar faraldsfræðilegar upplýsingar um próun áhættupátta fram til ársins 2013. Í peim tilvikum par sem um áður birt gögn er að ræða er vísað til viðeigandi heimilda, annars er um ný og áður óbirt gögn að ræða.

Hjartaáföll og dánartíðni af peirra völdum

Mikil lækkun hefur orðið á nýgengi kransæðasjúkdóma og dauðsfalla af peirra völdum á Íslandi allt frá $1981 .{ }^{1}$ Mynd 1a sýnir aldursstaðlað nýgengi kransæðasjúkdóma í aldurshópnum 25-74 ára fyrir tímabilið 1981-2009. Par má sjá að nýgengi kransæðasjúkdóma lækkaði um 66,5\% yfir tímabilið. Áberandi er lækkandi nýgengi á aldursbilinu 50-75 ára, bæði meðal karla og kvenna (mynd 1b) og skýrir pað að nokkru leyti aukið langlífi pjóðarinnar par sem hluti pessara áfalla verða síðar á ævinni en áður var.

Mynd 1c sýnir breytingar í aldursstaðlaðri dánartíðni vegna kransæðasjúkdóma fyrir 75 ára aldur á tímabilinu 1981-2015. Fækkun dauðsfalla var um 80\% fyrir tímabilið 1981-2006 og hefur haldið áfram í lok pessa tímabils pannig að lækkunin er orðin $86 \%$ fyrir 1981-2015 (85,7\% meðal karla og 86,2\% hjá konum) (mynd 1c).

Horfur peirra sem fá kransæðastíflu hafa batnað verulega á síðustu áratugum. ${ }^{3,4}$ Á mynd 2 er sýnd 28 daga lifun eftir fyrstu



Mynd 1b. Nýgengi kransæðasjúkdóma í fimm ára aldurshópum 25-74 ára, árin 1981 og 2009. 


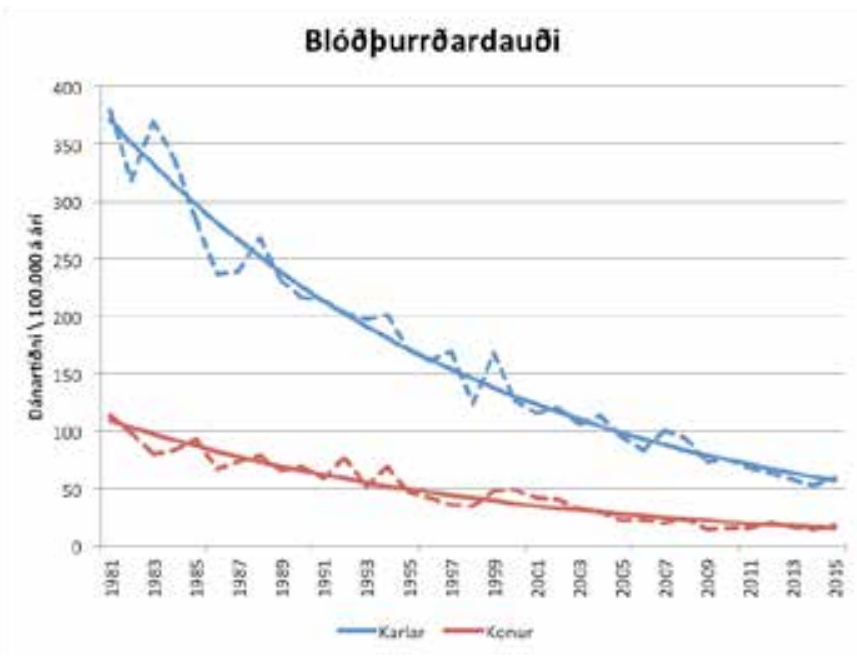

Mynd 1c. Aldursstöðluð dánartíðni blóðpurrðar-hjartasjúkdóma 25-74 ára, tímabilið 1981-2015.

kransæðastíflu 25-74 ára karla og kvenna fyrir tímabilið 1981-2009. Hér eru teknir með allir sem deyja innan 28 daga, par með talið dauðsföll utan sjúkrahúsa. Lifun peirra sem fá hjartastopp utan sjúkrahúsa par sem endurlífgun er reynd hefur ekki breyst marktækt á pessu tímabili og er nú um $25 \% .^{12}$

Á árabilinu 1990-2013 hefur meðalævilengd Íslendinga aukist um 4,8 ár. Par af eru 2,6 ár vegna lækkunar í dánartíðni hjarta- og æðasjúkdóma (www.healthdata.org). ${ }^{13}$ Hjá körlum hefur meðalævilengdin aukist um 5 ár og eru 2,6 ár vegna lækkunar í dánartíðni hjarta- og æðasjúkdóma. Hjá konum hefur meðal ævilengdin aukist um 4,6 ár, par af eru 2,1 ár vegna lækkunar í dánartíðni vegna hjarta- og æðasjúkdóma. Konur eru að meðaltali fimm árum eldri en karlar við fyrsta tilfelli kransæðastíflu.

Með vaxandi langlífi eykst hlutfall aldraðra verulega á næstu áratugum. Í dag eru um 15\% pjóðarinnar eldri en 67 ára en árið 2040 verður petta hlutfall um 23\%. Hlutfall vinnufærra (16-66 ára) á móti eftirlaunapegum lækkar úr 5,6 árið 2010 í 3,3 árið 2040 og í 2,6 árið 2060 (mynd 3). Vaxandi kostnaður af öldrun og meðferð langvinnra sjúkdóma lendir pví á æ færri höndum og mun hafa veruleg áhrif á allt hagkerfið pegar fram í sækir. ${ }^{6}$

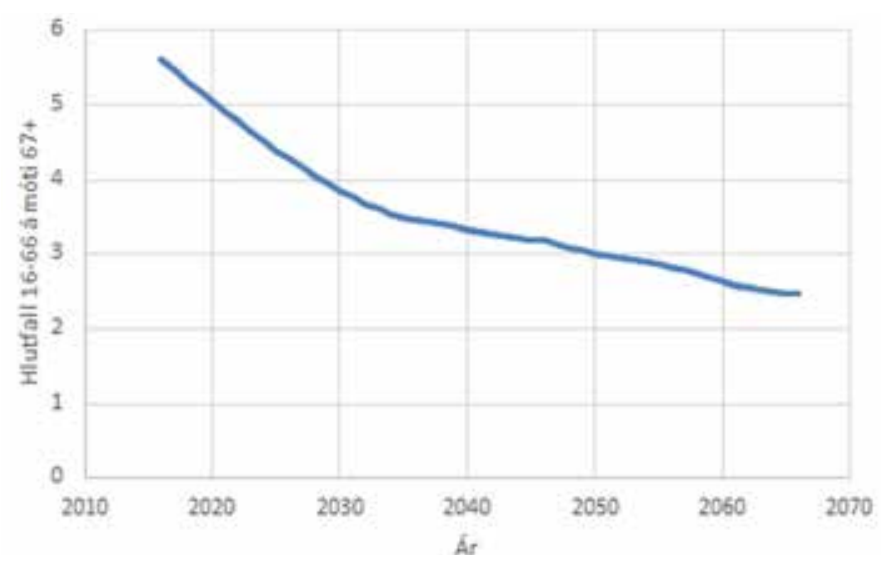

Mynd 3. Spá um mannfjölda á Íslandi 2010-2065. Hlutfall 16-66 ára á móti 67 ára og eldri. Hagstofan 2016.
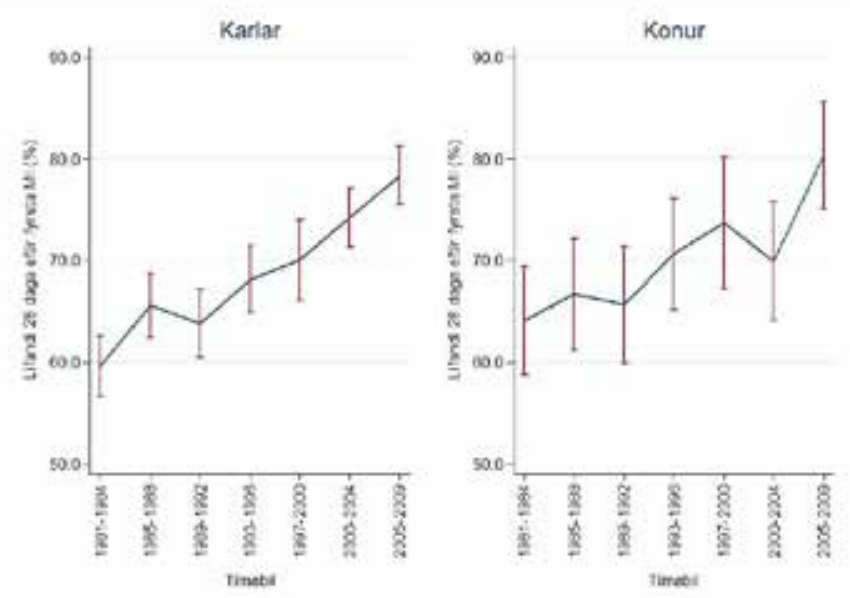

Mynd 2. Batnandi 28 daga lifun eftir fyrstu kransæðasstíflu 25-74 ára 1981-2009.

Reiknað hefur verið út frá gögnum Hjartaverndar að á árinu 2006 urðu nær 500 færri kransæðastíflutilfelli og 295 færri dauðsföll af peirra völdum á Íslandi en verið hefði ef staða helstu áhættupátta hefði haldist óbreytt frá árinu 1981. ${ }^{1}$ Ef petta er skoðað fyrir árið 2014 kemur í ljós að 405 færri ótímabær dauðsföll urðu pað árið en hefðu orðið ef óbreytt dánartíðni frá 1981 hefði enn verið við lýði.

Pegar leitað er skýringa á peim breytingum sem orðið hafa í nýgengi og dánartíðni vegna kransæðasjúkdóma koma annars vegar til álita breytingar í pekktum og ópekktum áhættupáttum og hins vegar breytt áhrif inngripa svo sem lyfjameðferðar og aðgerða. Próuð hefur verið reikniaferð sem metur innbyrðis vægi áhættupátta og meðferðar í dánartíðni vegna kransæðasjúkdóma, svokallað IMPACT módel. ${ }^{14-15}$ Petta reiknilíkan tekur mið af mældum breytingum í stöðu áhættupátta og notkun íhlutunar svo sem lyfjameðferðar og kransæðainngripa. Áhrif pessara pátta hafa verið sannreynd í fjölda sjálfstæðra rannsókna og eru vel pekkt. ${ }^{16-27-}$ Pegar algengi áhættupáttar eða íhlutunar er margfaldað með áhrifum hvers páttar má reikna út að hve miklu leyti breytt dánartíðni skýrist af breytingum í hverjum pætti fyrir sig. Petta reiknilíkan hefur verið notað á mælingar Hjartaverndar til að reikna út framlag áhættupátta og meðferðar í peirri fækkun dauðsfalla vegna kransæðasjúkdóma sem orðið hefur hér á landi á árunum 1981-2006. Pær niðurstöður sýndu að nærri 3/4 hlutar fækkunarinnar voru útskýrðir með breytingum á sex áhættupáttum og fjórðungur með læknisfræðilegum inngripum (lyfjameðferð og skurðaðgerðum). ${ }^{1}$

Stór hluti kransæðastíflu á sér stað án pess að viðkomandi geri sér grein fyrir áfallinu. Í Öldrunarrannsókn Hjartaverndar voru pátttakendur meðal annars rannsakaðir með segulómskoðun af hjarta. Par fundust tveir með ópekkt hjartaáfall fyrir hvern einn einstakling með pekkta sögu um kransæðastíflu. ${ }^{28}$ Horfur pessara einstaklinga með pögul áföll voru sambærileg við horfur peirra sem höfðu pekkta sögu um kransæðastíflu og voru marktækt verri en hjá peim sem voru með heilbrigð hjörtu. Рað er pví ljóst að umfang kransæðasjúkdóma er mun stærra vandamál en hefðbundin faraldsfræðileg gögn sýna. 

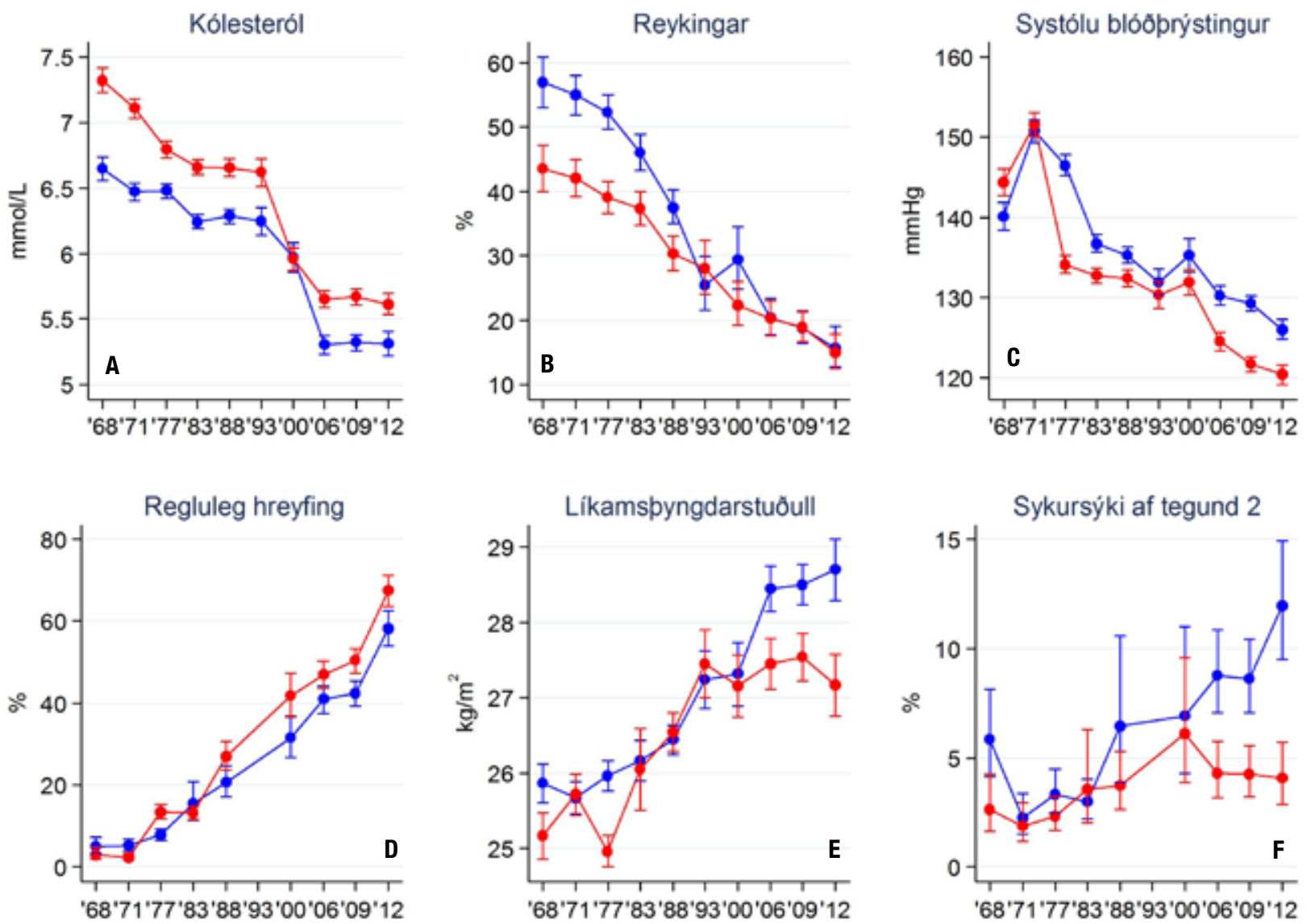

\begin{abstract}
Mynd 4. a) Lækkun í heildarkólesteróli í blóði 50-69 ára Íslendinga á tímabilinu 1968-2012. Lækkunin nemur 1,33 mmól/l eða 20,1\% meðal karla og 1,71 mmól/l eða 23,3\% meðal kvenna. Engin lækkun hefur orðið i meðaltalskólesteróli frá 2006-2012. b) Lækkandi algengi daglegra reykingamanna 50-69 ára á Íslandi á árabilinu 1968-2012. Reykingamönnum á pessu aldursbili hefur fækkað um 72\% hjá körlum og um 66\% meðal kvenna. Áframhaldandi fækkun miðaldra reykingamanna hefur mælst frá 2006-2012. c) Lækkandi slagbilsprýstingur 50-69 ára Íslendinga á árabilinu 1968-2012. Lækkunin nemur 10\% hjá körlum og 16,7\% meðal kvenna. Á tímabilinu 2006-2012 heldur slagbilsprýstingur áfram að̋ lækka, bæði meðal karla og kvenna. d) Vaxandi hlutfall reglubundinnar hreyfingar hjá 50-69 ára Íslendingum á árabilinu 1968-2012. Aukningin er margföld bæði meðal karla og kvenna og virðist heldur vera að aukast ef eitthvað er. e) Hækkandi líkamspyngdarstuðull 50-69 ára Íslendinga á árabilinu 1968-2012. Hækkunin er 11\% hjá körlum og 8\% hjá konum á tímabilinu. Á síðustu árum virðist pyngdaraukning halda áfram hjá körlum en standa í stað meðal kvenna.f) Algengi sykursýki 2 hefur aukist verulega hjá $50-69$ ára körlum á tímabilinu 1968-2012. Aukningin er rúmlega tvöföld meðal karla og 54\% hjá konum. Á árunum frá 2006-2012 heldur aukningin í sykursýki áfram meðal karla en stendur í stað hjá konum.
\end{abstract}

\section{Breytingar helstu áhættupátta og áhrif peirra á kransæðasjúkdóma}

\section{Kólesteról}

Um priðjung peirrar fækkunar (32\%) sem varð á dauðsföllum vegna kransæðasjúkdóma 1981-2006 mátti rekja til 0,87 mmól/1 (15\%) lækkunar á meðalgildi kólesteróls í blóði Íslendinga á pessu tímabili. ${ }^{1}$ Pessi lækkun gæti skýrst að nokkru leyti af breyttu mataræði Íslendinga á pessu tímabili, par sem mestu munar um minni heildarneyslu á fitu sem hlutfall orkueininga (E\%) úr $41 \%$ í $36 \%$ og mettaðrar fitu úr 20E\% í 14,5E\% á tímabilinu 1990-2011. ${ }^{29}$ I kjölfar pessarar jákvæðu próunar virðist sem fituneysla Íslendinga sé aftur á uppleið. Hlutfall mettaðrar fitu af heildarorkupörf (E\%) var 15,2\% árin 2010-2011, sem er talsvert yfir manneldisráðleggingum sem gera ráð fyrir að petta hlutfall sé undir $10 \% .{ }^{29-31}$ Í nýlegri skýrslu Norrænu ráðherranefndarinnar kemur fram að mataræði 40,2\% Íslendinga einkenndist af mikilli mettaðri fitu árið 2014 og hefur pað hlutfall hækkað um 26\% frá árinu 2011.32 Pessi aukna fituneysla gæti átt pátt í pví að áðurnefnd lækkun í meðaltalsgildi kólesteróls hefur stöðvast á allra síðustu árum (mynd 4a).

Ef horft er til tímabilsins 1968-2012 má sjá að meðaltal kólesteróls hjá miðaldra (50-69 ára) Íslendingum hefur lækkað um 1,33 mmól/1, eða 20,1\%, meðal karla og um 1,71 mmól/1, eða 23,3\%, meðal kvenna. Jafnframt má sjá að sú lækkun í meðaltali kólesteróls sem staðið hefur samfellt frá 1968 hefur stöðvast eftir 2006, bæði meðal karla og kvenna (mynd 4a). Pessi próun er í samræmi við áðurnefndar breytingar í mataræði Íslendinga og kemur heim og saman við framtíðarspá sem sett var fram nýlega um próun áhættupátta á Íslandi og áhrif peirra á hækkandi dánartíðni vegna hjartaáfalla í öllum aldurshópum. ${ }^{2}$

Vert er að hugleiða hvers vegna meðaltalsgildi kólesteróls hafa hætt að lækka eftir árið 2006, á sama tíma og almenn notkun blóðfitulækkandi lyfja (statína) hefur stóraukist. Skilgreindum dagskömmtum (DDD) statínlyfja sem seldir voru á Íslandi fjölgaði úr 60 í 88,5 á hverja púsund íbúa, eða um 48\%, á árabilinu 2007 til 


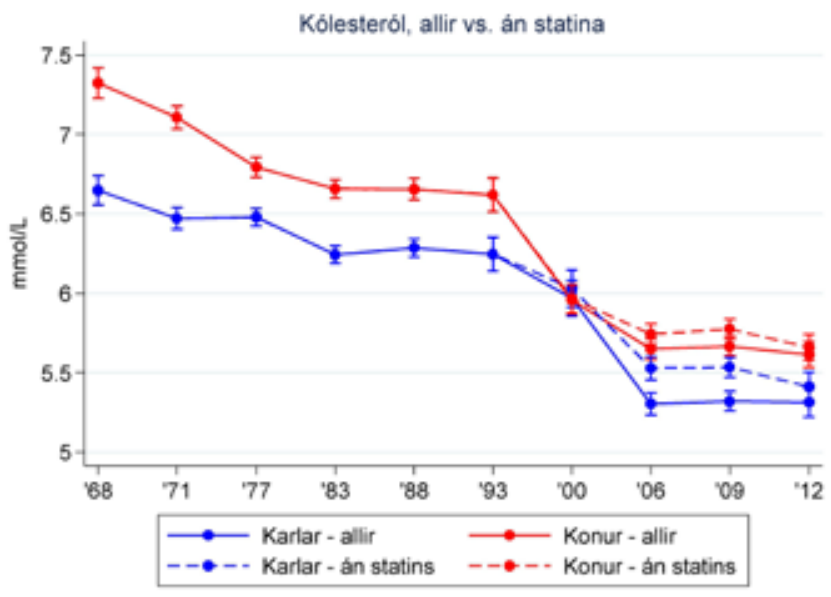

Mynd 5. Meðaltal kólesterólgilda hjá körlum og konum með og án statínlyfja.

2015 (heimild: lyfjagagnagrunnur landlæknis). Á sama hátt hefur fjöldi peirra sem taka statínlyf aukist um 56\% á sama tímabili, sem er að meðaltali 6,2\% aukning á ári. Rannsókn Hjartaverndar sýndi fram á að lækkunin á meðalgildi kólesteróls 1967-2008 hafði orðið fyrst og fremst vegna lífsstílsbreytinga en óverulega vegna notkunar blóðfitulækkandi lyfja (statínlyf) eins og gjarnan hefur verið haldið fram. Pessar niðurstöður vöktu athygli par sem sýnt var fram á að unnt er að hafa áhrif á lífsstíl heillar pjóðar og ná árangri í að bæta áhættupætti sjúkdóma. ${ }^{33}$ Með ört vaxandi notkun statínlyfja á allra síðustu árum gæti petta hafa breyst. Leiða má líkur að pví að pessi stóraukna notkun statínlyfja á síðasta áratug hefði áhrif til lækkunar meðaltals kólesteróls í pessum aldurshópi. Á mynd 5 eru sýnd meðaltals kólesterólgildi karla og kvenna, annars vegar án tillits til statín-meðferðar (heilar línur) og hins vegar pegar peir sem taka statínlyf hafa verið teknir út (brotnar línur). Í ljós kemur að meðaltals kólesterólgildi hafa staðið nokkurn veginn í stað eftir 2006, bæði hjá peim sem ekki taka statínlyf og í heildarhópnum pó að meðaltalsgildin séu marktækt lægri hjá peim síðarnefndu.

\section{Tóbaksreykingar}

Annar áhættupáttur sem breyst hefur verulega til hins betra er tóbaksreykingar. Á tímabilinu 1981-2006 lækkaði algengi daglegra reykinga hjá Íslendingum yngri en 75 ára úr $47 \%$ í $23 \%$. pessi æskilega breyting skýrði um $22 \%$ af peirri fækkun dauðsfalla vegna kransæðasjúkdóma sem varð á tímabilinu. ${ }^{1}$ Algengi reykinga hefur haldið áfram að lækka enda pótt enn reyki um 15\% miðaldra fólks. ${ }^{34}$ Á tíunda áratug síðustu aldar var priðja hvert dauðsfall í aldurshópi 35-69 ára tengt reykingum. Á pessum tíma dó að meðaltali einn Íslendingur á dag úr reykingatengdum sjúkdómum (hjarta og æðasjúkdómar, lungnasjúkdómar og krabbamein) samkvæmt útreikningum Hjartaverndar. ${ }^{35}$ Á árinu 2006 voru dauðsföll af völdum reykingatengdra sjúkdóma nærri 100 færri á ári en árið 1981. ${ }^{1}$ Samkvæmt rannsókn Nikulásar Sigfússonar frá 2006 hafa pær rannsóknir sem mæla algengi reykinga með einni könnun vanmetið skaðleg áhrif reykinga um 15-40\%. ${ }^{36}$ Ef horft er til tímabilsins 1968-2012 meðal 50-69 ára Íslendinga má sjá að hlutfall daglegra reykingamanna hefur lækkað úr 57\% í 16\%, eða um $72 \%$, hjá körlum og úr $44 \%$ í $15 \%$, eða um $66 \%$, hjá konum. Algengið er nú svipað hjá báðum kynjum par sem notkunin var áður fyrr mun meiri meðal karla en kvenna (mynd 4b). Pessar niðurstöður eru í samræmi við framtíðarspá um próun kransæðasjúkdóma sem Hjartavernd hefur áður birt.² Algengi daglegra reykinga hjá fullorðnum á Íslandi er með pví lægsta sem pekkist og hefur lækkað hraðast af Norðurlöndunum á undanförnum árum. ${ }^{32}$ Reykingamenn eru hlutfallslega flestir meðal peirra sem standa efnahagslega og félagslega höllum fæti í í samfélaginu. ${ }^{32}$ Við erum komin í endataflið í baráttunni við reyktóbakið pví að reiknað er með að pað takist með öllu að útrýma reykingum ef algengið fer niður undir 5\%. Раð eru pó blikur á lofti og margt óljóst um hvaða áhrif ný form nikótíns (rafsígarettur, munntóbak) koma til með að hafa á nikótínfíkn og tóbaksnotkun á komandi árum. ${ }^{34,37,39}$

\section{Blóðprýstingur}

Priðji helsti áhættupátturinn, slagbilsblóðprýstingur, hefur lækkað að meðaltali um $5 \mathrm{mmHg}$ í aldurshópi 25-74 ára á tímabilinu 1981-2006. Pessi lækkun blóðprýstings skýrir 22\% af fækkun kransæðadauðsfalla á pessu tímabili. ${ }^{1}$ Lækkunin endurspeglar bæði lyfjanotkun við háprýstingi og lækkun í almennu pýði.

Ef horft er til tímabilsins 1968-2012 fyrir miðaldra Íslendinga (50-69 ára) má sjá að meðaltal slagbilsprýstings hefur lækkað um 14,0 mmgHg hjá körlum, sem er 10\% lækkun. Hjá konum hefur lækkunin á tímabilinu verið $24,0 \mathrm{mmHg}$, sem er 16,7\%. Á árunum 2006-2012 virðist meðalslagbilsprýstingur halda áfram að lækka bæði meðal karla og kvenna og er farinn að nálgast hagstæðustu gildi með tilliti til líffæraskemmda (115 mmHg $)^{40}$ (mynd 4c).

Pegar leitað er skýringa á lækkandi blóðprýstingi verður bæði að horfa til undirliggjandi áhrifapátta svo sem erfða og saltneyslu og hins vegar til áhrifa meðferðar.

Aukin saltneysla skýrir um pað bil 10\% af heildarfjölda dauðs-

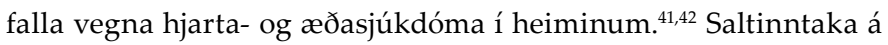
Íslandi hefur pó staðið nokkurn veginn í stað á árabilinu 1990 til 2010 en er samt sem áður um pað bil $9 \mathrm{~g} / \mathrm{dag}$ að meðaltali, sem jafngildir 3,6 g/dag af natríum og er næstum tvöfalt pað magn sem WHO mælir með. ${ }^{42}$ Pað er pví ólíklegt að breyting á saltinntöku skýri ein og sér fyrrnefnda lækkun í meðaltali blóðprýstings hér á landi. Líklega vega aðrir pættir pyngra.

Í doktorsritgerð Nikulásar Sigfússonar 1981 var sýnt fram á verulega aukningu í meðvitund peirra sem höfðu háprýsting á árabilinu frá 1967-1981 pegar hún jókst frá 24\% í 68\%. Samhliða pessu jókst hlutfall peirra sem voru á meðferð við háprýstingi úr $16 \%$ í $64 \%$. Algengi háprýstings var um $44 \%$ meðal karla og $38 \%$ hjá konum árið 2010 en af peim sem höfðu verið greindir voru einungis 70\% á lyfjameðferð. Í Öldrunarrannsókninni 2004 voru $81 \%$ einstaklinga með háprýsting og $64 \%$ voru á blóðprýstingslækkandi meðferð. Af peim sem höfðu pekktan háprýsting voru hins vegar 91\% meðhöndlaðir. ${ }^{43}$ Meðferðarhlutfallið er pví lægra í yngri aldurshópum, sem er áhyggjuefni. Pekkt er að af peim sem eru á blóðprýstingslækkandi meðferð er minna en helmingur sem nær meðferðarmarkmiðum. ${ }^{44}$ Prátt fyrir að mikið hafi áunnist í meðvitund um háprýsting pá hefur lyfjameðferð ekki skilað peim 


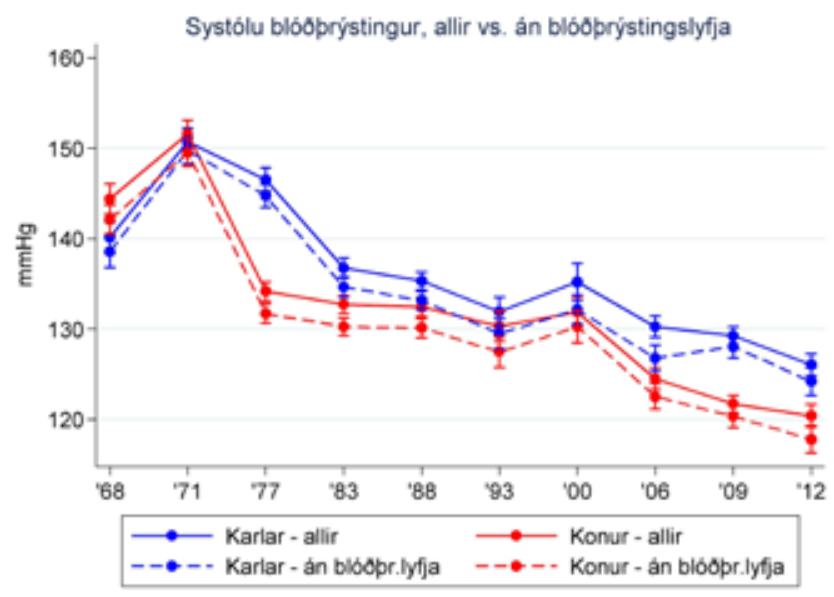

Mynd 6. Meðaltal blóðprýstings gilda hjá körlum og konum með og án blóðprýstingslækkandi lyfja.

árangri sem vonast var eftir. Á mynd 6 má sjá samanburð á meðaltals blóðprýstingsgildum hjá 50-69 ára Íslendingum eftir pví hvort peir tóku blóðprýstingslækkandi lyf eða ekki. Athyglisvert er að blóðprýstingur er að meðaltali hærri hjá peim sem notuðu slík lyf heldur en í almennu pýði án blóðprýstingslyfja pótt báðir hópar sýni sams konar feril í lækkun blóðprýstings. Petta bendir til almennra sameinginlegra pátta sem hafa haft áhrif til lækkunar blóðprýstings hjá pjóðinni. Petta endurspeglar einnig pá staðreynd að peir sem nota blóðprýstingslækkandi lyf eru að jafnaði ekki að ná meðaltalsgildum ómeðhöndlaðra og er sú niðurstaða í samræmi við pað sem sést hefur í erlendum rannsóknum. ${ }^{44}$ Að líkindum má skýra stóran hluta peirrar lækkunar sem orðið hefur í meðaltalsblóðprýstingi undanfarna áratuga með aukinni hreyfingu, minni reykingum og heilbrigðari lífsstíl.

\section{Reglubundin hreyfing}

Reglubundin hreyfing í frístundum hefur reynst sjálfstæður verndandi páttur gegn kransæðasjúkdómum samkvæmt niðurstöðum Hjartaverndarrannsóknarinnar (heimild: Handbók Hjartaverndar (http://www.hjarta.is/utgafa/handbok-hjartaverndar)). Á árinu 1981 stundaði um fjórðungur Íslendinga líkamshreyfingu í frístundum en næstum helmingur á árinu 2006. Pessi æskilega breyting skýrði um 5\% af peirri fækkun dauðsfalla vegna kransæðsjúkdóma sem varð á tímabilinu 1981-2006. ${ }^{1}$

Pegar litið er til tímabilsins 1968-2012 sést að hlutfall miðaldra karlmanna (50-69 ára) sem hreyfa sig reglulega hefur aukist úr 5\% í 58\%. Hjá konum er aukningin úr 3\% í 68\%. Á mynd 4d) má sjá að pessi próun hefur haldið áfram frá 2006, bæði hjá konum og körlum. Prátt fyrir pessa aukningu í reglulegri hreyfingu hér á landi komum við næst á eftir Norðmönnum sem hafa hæst hlutfall hreyfingarleysis meðal Norðurlandapjóða. ${ }^{32}$ Aukin hreyfing i frístundum og á leið í og úr vinnu eru dæmi um pað hvaða áhrif vitundarvakning meðal pjóðarinnar getur haft í átt að heilbrigðum lífsstíl og gildi hreyfingar. Breytt borgarskipulag sem gerir ráð fyrir gangandi og hjólandi umferð og ívilnun margra vinnuveitenda til handa peim sem ferðast bíllaust í vinnuna er dæmi um hvaða áhrif upplýsingar og bætt aðgengi að hreyfingu geta haft á heilbrigði pjóðar. ${ }^{45}$

\section{Ofpyngd og offita}

Íslendingar pyngjast stöðugt. Líkamspyngdarstuðull $\left(\mathrm{kg} / \mathrm{m}^{2}\right)$ hefur á tímabilinu 1981 til 2006 hækkað að meðaltali um 2 stig, eða úr 25 í 27. Líkamspyngd karla hefur aukist að meðaltali um $8 \mathrm{~kg} \mathrm{og}$ kvenna um 7 kg miðað við sömu líkamshæð. Pessi aukna líkamspyngd jók dánartíðni vegna kransæðasjúkdóma um $4 \%$ á pessu sama tímabili og dró pannig úr jákvæðum heildaráhrifum flestra annarra áhættupátta sem próuðust í jákvæða átt.

pegar litið er til tímabilsins 1968-2012 fyrir miðaldra karla sést að líkamspyngdarstuðullinn hefur hækkað úr $25,8 \mathrm{~kg} / \mathrm{m}^{2}$ í 28,7 kg/ $\mathrm{m}^{2}$, eða um $2,9 \mathrm{~kg} / \mathrm{m}^{2}$, sem er aukning um $11 \%$. Hjá konum $50-69$ ára hefur líkamspyngdarstuðull hækkað um $2 \mathrm{~kg} / \mathrm{m}^{2}$, eða úr 25,2 $\mathrm{kg} / \mathrm{m}^{2}$ í $27,2 \mathrm{~kg} / \mathrm{m}^{2}$ og er pað aukning um $8 \%$. Eins og sjá má á mynd 4e) virðist pyngd miðaldra kvenna standa nokkurn veginn í stað frá 2006 til 2012 á meðan karlmenn halda áfram að pyngjast. Íslendingar eru nú ofarlega meðal Evrópupjóða með tilliti til líkamspyngdar ${ }^{46}$ og langpyngstir Norðurlandapjóða. ${ }^{32}$ Hlutfall Íslendinga í ofpyngd (LPS 25-29,9) er 57,9\% og 22,2\% eru með offitu (LPS $>30)$. Ísland er eina landið á Norðurlöndum par sem algengara er að vera í of pyngd eða of feitur en í kjörpyngd. ${ }^{32}$ Skýringarinnar kann að vera að leita í mataræði landsmanna. Hlutfall peirra sem hafa óhollt mataræði með háu innihaldi mettaðrar fitu og viðbætts sykurs er hátt á Íslandi, eða 24,5\%, og einungis Svípjóð er með hærra hlutfall af óhollu mataræði af Norðurlöndunum. Einkennandi fyrir mataræði Íslendinga er hátt hlutfall peirra sem borða mikið sætmeti og erum við par langhæst meðal Norðurlanda. Á meðan flest Norðurlönd eru að draga saman í sykurneyslu stendur hún í stað hér á landi og í Svípjóð. Um priðjungur af öllum viðbættum sykri í mataræði Íslendinga kemur úr gosdrykkjum og sykruðum svaladrykkjum. Annað sem einkennir mataræði Íslendinga er mjög lítil neysla grænmetis og ávaxta samanborið við önnur Norðurlönd par sem einungis 7\% pjóðarinnar borða að minnsta kosti fimm einingar grænmetis og ávaxta á dag og erum við par rúmlega hálfdrættingar við meðaltal Norðurlandapjóða. Við erum hins vegar fremst meðal Norðurlanda í fiskneyslu og borðum fisk að meðaltali tvisvar í viku. ${ }^{32}$ Pessi ofneysla sykurs og almenn óhollusta í mataræði stuðlar að ofpyngd og offitu pjóðarinnar og á pátt í pví að algengi sykursýki fer vaxandi.

\section{Sykursýki}

Aukin líkamspyngd hefur haft veruleg áhrif á próun sykursýki af tegund 2 sem jafnframt er vel pekktur áhættupáttur kransæðasjúkdóma og tvöfaldar líkurnar á pví að fá kransæðastíflu miðað við einstaklinga sem ekki hafa sykursýki. ${ }^{47}$ Á milli áranna 1981 og 2006 hafði orðið tvöföldun í algengi sykursýki 2 úr 1,7\% 1́ 3,6\% hjá pjóðinni og skýrði pessi breyting 4,6\% aukningu í dánartíðni vegna kransæðsjúkdóma á tímabilinu. ${ }^{1}$

Samanlagt hafði pví aukin líkamspyngd og hærra algengi sykursýki af tegund 2 í för með sér meiri áhættu á dauðsföllum af völdum kransæðasjúkdóma sem nam um 9\% á tímabilinu 19812006. Fyrir 30 árum var pessi tegund sykursýki verulega fágætari 


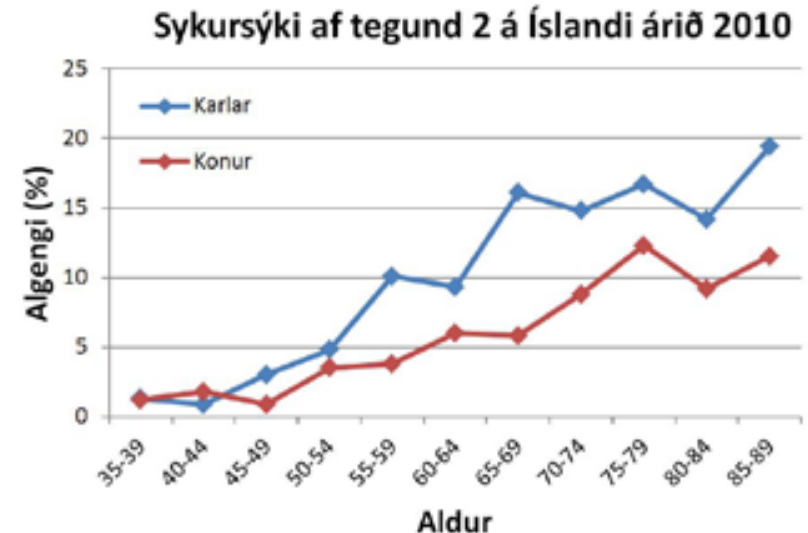

Mynd 7. Algengi sykursýki 2 á Íslandi 2010 eftir aldursflokkum.

á Íslandi en á hinum Norðurlöndunum en nú er algengi hennar svipað eða jafnvel hærra en par. Algengi sykursýki af tegund 2 meðal 25-94 ára karla á Íslandi 2010 var 7\% (vikmörk 6\%-8\%) og meðal 25-94 ára kvenna var algengið 4\% (vikmörk 3\%-5\%) (mynd 7). Að jafnaði hefur algengi í pessum hópi hækkað um 3\% á ári hjá körlum en um $2 \%$ á ári hjá konum. Áætlaður fjöldi með sykursýki af tegund 2 á Íslandi er um 14000 manns par sem um 63\% eru karlar.

Ef litið er til árabilsins 1968-2012 hjá körlum 50-69 ára, má sjá að algengi sykursýki 2 hefur rúmlega tvöfaldast, úr pví að vera tæplega 6\% í 12\%, eða um 105\%. Á sama tímabili virðist algengi sykursýki meðal 50-69 ára kvenna hafa aukist hægar, úr 2,6\% í 4,1\%, eða um 54\%. Pegar horft er tímabilsins eftir 2006 sést að algengi sykursýki meðal karlmanna hefur aukist hratt en stendur í stað meðal kvenna (mynd 4f). Pessar breytingar haldast í hendur við pá pyngdaraukningu sem fram kemur í mynd 4e) án pess að fullyrt verði að um beint orsakasamband sé að ræða.

Algengi sykursýki 2 virðist hækka línulega eftir miðjan aldur, bæði hjá konum og körlum, og helst sú aukning fram á elstu aldurshópa að minnsta kosti meðal karla (mynd 7). Búast má við pví að pessi aukning í ofpyngd og sykursýki 2 eigi eftir að leiða til aukningar í langvinnri hjartabilun og um leið skertra lífsgæða og aukinnar sjúkdómsbyrði aldraðra. ${ }^{48}$ Áhrif lífsstíls á erfðaupplag kemur pví óvíða skýrar fram en í próun sykursýki 2. Önnur rannsókn Hjartaverndar hefur pó bent til verulega minni áhættu á kransæðasjúkdómum meðal aldraðra í pessum hópi ef peir taka kólesteróllækkandi lyf (statín). Pessi rannsókn sýndi fram á að einstaklingar eldri en 70 ára sem höfðu sykursýki 2 og voru ekki á statínlyfjum voru 3,5 sinnum líklegri til að deyja úr hjartaáfalli en peir sem fengu blóðfitulækkandi lyfjameðferð með statínum. ${ }^{49}$

\section{Áhrif mataræðis á próun hjarta- og æðasjúkdóma}

Í pessari yfirlitsgrein er notast við lýsandi faraldsfræði á áhættupáttum og nýgengi kransæðasjúkdóma með stöðluðum vísindalegum aðferðum. Breytingar á einstökum áhættupáttum eru skoðaðar í ljósi mældra breytinga sem orðið hafa á lífsstíl, mataræði og hreyfingu. Ekki er gerð tilraun til pess að álykta að beint orsakasamband sé á milli vissra fæðutegunda og próunar hjarta- og æðasjúkdóma enda er slík umfjöllun handan við tilgang pessarar yfirlitsgeinar. Hins vegar liggur ljóst fyrir að hátt gildi LDL-kólesteróls í blóði tengist með öðru próun æðakölkunarsjúkdóma. Samspil mataræðis, kólesteróls og nýgengis kransæðasjúkdóma er flókið og tekur breytingum yfir tíma. Mismunandi aðstæður eiga við í mismunandi löndum. Erfitt er að framkvæma slembiraðaðar klínískar rannsóknir á áhrifum mataræðis yfir löng tímabil. Pannig eru ekki öll kurl komin til grafar varðandi beint orsakasamband milli hlutfalls fitu og kolvetna í fæðu og próun kransæðasjúkdóma. Nýlega birt faraldsfræðileg rannsókn sem gerð var í 18 löndum og tók til rúmlega 135 púsund einstaklinga, 35-70 ára, hefur verið túlkuð á pann veg að nýgengi hjarta- og æðasjúkdóma tengist ekki aukinni fituneyslu heldur mikilli neyslu kolvetna. ${ }^{50}$ Pegar betur að gáð styðja niðurstöður PURE rannsóknarinnar pó við manneldismarkmið okkar um að draga úr neyslu mettaðrar fitu undir 10\%E enda er nýgengi kransæðastíflu lægst í peim hópi en við erum nú með um 15,2\%E í mettaðri fitu. Hvað varðar kolvetni er Norræna neysluviðmiðið að neysla á kolvetnum sé 45-60\%E. Í Norrænu mataræði er prósentan 43-52\%E sem samsvarar 2 neðstu fimmtungum (quintiles) í PURE rannsókninni, sem er langt undir peim mörkum sem sýndi aukna tíðni heilablóðfalla (66-77\%E). Pessi rannsókn gefur pví ekki tilefni til að breyta núgildandi ráðleggingum eða hvetja almennt til svonefnd lágkolvetnamataræðis í pví augnamiði að draga úr nýgengi hjarta- og æðasjúkdóma. Áhrif pessara fæðuflokka á nýgengi sykursýki og offitu voru ekki metin í PURE-rannsókninni.

\section{Framtíðarspá}

Breytingar í helstu áhættupáttum kransæðasjúkdóma á árabilinu 1980-2006 skýrðu um prjá fjórðu hluta peirrar lækkunar sem sást í dánartíðni af völdum kransæðasjúkdóma á tímabilinu. ${ }^{1}$ Aðeins tveir áhættupættir, offita og sykursýki, próuðust í gagnstæða átt og drógu talsvert úr pessari lækkun á dánartíðni. Pegar rýnt er í próun helstu áhættupátta á síðustu sex árum má sjá að verulega dregur úr peirri jákvæðu próun sem sást síðustu prjá áratugina eða hún hverfur jafnvel alveg. ${ }^{2}$

Pannig hefur meðaltal kólesterólgilda hjá miðaldra Íslendingum hætt að lækka á nýliðnum árum, bæði meðal kvenna og karla. Hlutfall peirra sem reykja daglega í hópi miðaldra Íslendinga heldur áfram að lækka. Meðaltal slagbilsprýstings heldur áfram að lækka hjá báðum kynjum á aldursbilinu 50-69 ára með svipuðum hætti og undanfarna áratugi. Aukning á reglubundinni hreyfingu heldur áfram hjá báđum kynjum en pó hefur talsverð pyngdaraukning orðið meðal miðaldra karla. Petta endurspeglast í pví að algengi sykursýki 2 fer hratt vaxandi meðal miðaldra karla en eykst hægar hjá konum og stendur jafnvel í stað á allra síðustu árum. Búast má við pví að pessar breytingar á stöðu helstu áhættupátta, vaxandi offita og nýgengi sykursýki 2, muni leiða til verulegrar aukningar á nýgengi kransæðasjúkdóma og dauðsfalla af peirra völdum á komandi áratugum. ${ }^{2}$

Í rannsókn Rósu Bjarkar Pórólfsdóttur og samstarfsfólks hennar í Hjartavernd var rýnt í pessar breytingar á próun helstu áhættupátta og reynt að spá fyrir um áhrif breytinganna á dauðsföll af völdum kransæðasjúkdóma á Íslandi fram til 2040. ${ }^{2}$ Í peirri vinnu var byggt á sömu sex áhættupáttum og stuðst var við í rannsókninni 1981-2006 og aðferðafræði IMPACT-reiknilíkansins 


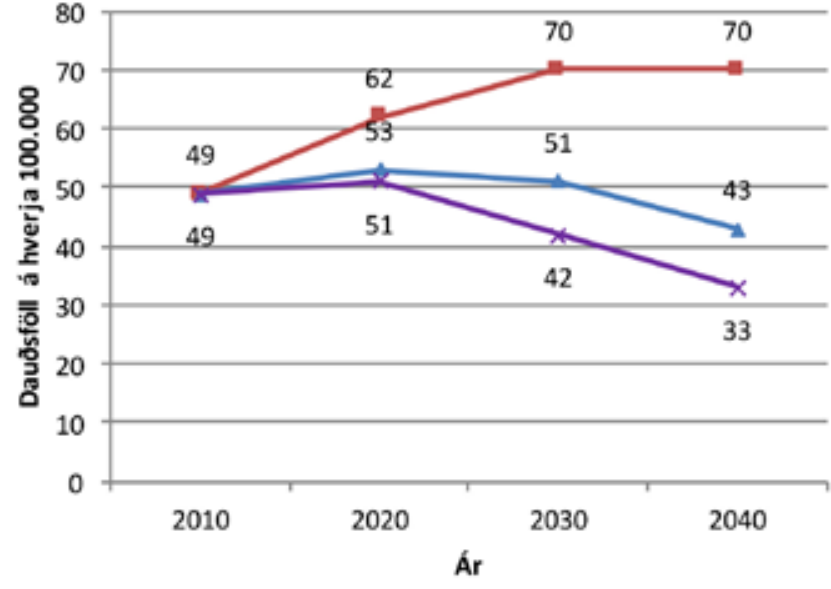

Mynd 8. Próun dauðsfalla vegna kransæðasjúkdóma reiknað út frá premur mismunandi forsendum. I fyrsta lagi: ef próun síðustu priggja áratuga heldur áfram óbreytt mun draga verulega úr fækkun dauðsfalla sem skýrist af öldrun pjóðarinnar. Í öðru lagi: ef gert er ráð fyrir að próun áhættupáttanna haldi áfram með sama hætti og sídustu 5 árin (2006-2010) pá mun dauðsföllum vegna kransæðasjúkdóma fjölga á ný, fyrst og fremst vegna aukningar i offitu og sykursýki ásamt öldrun pjóðarinnar. I priðja lagi: ef við göngum út frá poi að raunhæfum markmiðum verði náð með bætingu helstu áhættupátta fram til ársins

\section{- Nýleg próun (2006-2010) heldur áfram \\ - próun siôustu áratuga (1981-2010) heldur áfram \\ $\rightarrow$ Raunhæf markmið}

2040, pá mun verða lækkun í dánartíðni vegna kransæðasjúkdóma.

notuð. Hins vegar var stuðst við mannfjöldaspá Hagstofu Íslands 1 aldurshópum yngri en 75 ára. Sú spá gerir ráð fyrir tvöföldun á mannfjölda í aldurshópi 65-74 ára til ársins 2040, 35\% fjölgun í aldurshópi 55-64 ára en óverulegri breytingu í öðrum aldurshópum eldri en 25 ára.

Í rannsókninni var gengið út frá premur mismunandi forsendum í próun áhættupátta fram til ársins 2040. Í fyrsta lagi: ef próun síðustu priggja áratuga (1981-2010) heldur áfram óbreytt, mun verulega draga úr fækkun dauðsfalla vegna kransæðasjúkdóma og skýrist pað að miklu leyti af öldrun pjóðarinnar. Í öðru lagi: ef gert er ráð fyrir að próun áhættupáttanna haldi áfram með sama hætti og síðustu 5 ár tímabilsins (2006-2010), pá mun dauðsföllum vegna kransæðasjúkdóma fjölga úr 49/100 púsund í 70/100 púsund, eða um 43\%, fram til ársins 2040 (mynd 8). Pessi aukning stafar fyrst og fremst af aukinni offitu og sykursýki ásamt öldrun pjóðarinnar. Í priðja lagi: ef við göngum út frá pví að raunhæfum markmiðum verði náð með bætingu helstu áhættupátta fram til ársins 2040, pá mun verða lækkun í dánartíðni vegna kransæðasjúkdóma úr 49/100 púsund í 33/100 púsund, eða um 33\% frá pví sem var árið 2010 (mynd 8).

Niðurstöður pessara síðustu mælinga á próun áhættupátta styðja við pá framtíðarspá sem fram kemur í grein Rósu Bjarkar frá 2011. ${ }^{2}$ Allt bendir til pess að áframhaldandi aukning í offitu og sykursýki muni leiða til aukningar á dauðsföllum vegna hjarta- og æðasjúkdóma á komandi áratugum.

Hér parf að spyrna við fótum. Með markvissum lýðgrunduðum inngripum má bæta verulega stöðu helstu áhættupátta og pannig draga úr sjúkdómsbyrði í framtíðinni. ${ }^{51}$ Verði ekkert að hafst er ljóst að dauðsföllum vegna kransæðasjúkdóma mun fjölga verulega á komandi árum með fyrirsjáanlegum afleiðingum á stöðu langvinnra sjúkdóma, svo sem hjartabilunar. Fyrirsjáanleg afleiðing pessarar próunar ásamt vaxandi öldrun pjóðarinnar er að hjartabiluðum á eftir að fjölga umtalsvert meðal aldraðra Íslendinga á komandi árum. Reiknað er með að hjartabiluðum í hópi 70 ára og eldri eigi eftir að fjölga 2,3-falt fram til 2040 og prefaldast fyrir 2060.52 Pá eru ótalin pau áhrif sem pessi próun hefur á heilsutengd lífsgæði og versnandi félagslega stöðu aldraðra sem lifa síðustu æviárin við skerta færni og minnkað sjálfstæði, sem má að miklu leyti rekja til afleiðinga hjarta- og æðasjúkdóma og annarra langvinnra sjúkdóma sem koma hefði mátt í veg fyrir með fyrirbyggjandi aðgerðum.

\section{Öldrun pjóðarinnar}

Hér á undan hefur verið fjallað um svokölluð ótímabær dauðsföll af völdum kransæðasjúkdóma. Með pví er átt við dauðsföll fyrir 75 ára aldur. Öldrunarrannsókn Hjartaverndar á Íslendingum 67 ára og eldri hefur sýnt að tveir priðju aldraðra sem fá hjartaáföll lifa pað af en allt að 40\% peirra próa með sér hjartabilun á næstu árum (óbirt gögn Hjartaverndar). Sú próun að hjartaáföllum fækkar í yngri aldurshópunum leiðir til pess að pau verða að meðaltali síðar á lífsleiðinni en var fyrir nokkrum áratugum. Bætt lifun eftir hjartaáfallið pýðir að sífellt stækkandi hópur aldraðra lifir síðustu áratugi ævinnar með langvinnar afleiðingar hjartaáfalla, svo sem hjartabilun og hjartsláttartruflanir. Aldraðir verða sífellt hærra hlutfall pjóðarinnar. Petta undirstrikar pví mikilvægi pess að tefja eða koma í veg fyrir slík áföll meðal aldraðra í framtíðinni.

\section{Forvarnir kransæðasjúkdóma á komandi áratugum}

Af framansögðu er ljóst að forvarnir hjarta- og æðasjúkdóma muni taka nokkrum breytingum á komandi áratugum. Til pess að draga úr sjúkdómsbyrði aldraðra vegna kransæðasjúkdóma og auka á heilbrigði öldrunar er pví mikilvægt að greina æðasjúkdóminn fyrr og hefja meðferð pegar pað á við. Ein leið til pess er að skima miðaldra og eldri einstaklinga með nýjum aðferðum sem taka bæði til hefðbundinna og nýrra áhættupátta og næmum aðferðum við greiningu æðakölkunar. Ómskoðanir af hálsslagæðum hafa pann kost að vera ódýrar og hættulausar í framkvæmd en hafa jafnframt sterkt forspárgildi um æðakölkunarsjúkdóm í kransæðum. ${ }^{53}$ Með pessari rannsókn má bæta hefðbundið áhættumat með áhættureiknivél og finna pá einstaklinga sem eru einkennalausir og teljast með lága áhættu samkvæmt hefðbundnu mati. Annar veigamikill páttur í forvörnum næstu áratuga verður að draga úr offitu og sykursýki af hennar völdum.

Við erum langt frá pví að ná lýðheilsumarkmiðum í neyslu grænmetis og ávaxta og purfum að bæta okkur verulega par. $^{54}$ Sömuleiðis er óhófleg sykurneysla Íslendinga mikið áhyggjuefni sem verður að bregðast við með lýðgrunduðum inngripum. Pannig eru helstu áhersluatriði í forvörnum hjarta- og æðasjúkdóma að nokkru leyti önnur en pau hafa verið á undanförnum áratugum. Til pess að ná árangri í forvarnaraðgerðum er nauðsynlegt 
að pekkja til peirra pátta sem stuðla að sjúkdómsmyndun á hverjum tíma og beita markvissum inngripum sem skila árangri. ${ }^{15,55}$

\section{Samantekt}

Í pessari yfirlitsgrein höfum við rakið próun helstu áhættupátta kransæðasjúkdóma á Íslandi síðastliðna hálfa öld. Eftir tímabil stöðugra framfara sem einkenndist af pví að reykingamönnum fækkaði, meðaltals blóðprýstingur lækkaði og meðaltal kólesterólgilda lækkaði eru nú blikur á lofti. Hér eru birt ný gögn úr smiðju Hjartaverndar par sem fram kemur að verulega hefur dregið úr jákvæðri próun flestra áhættupátta en offita og sykursýki eru á hraðri uppleið. Að óbreyttu munu pessir ógnandi áhættupættir leiða til pess að nýgengi kransæðasjúkdóma fer vaxandi á ný á allra næstu árum, sérstaklega í hópi aldraðra. Áréttað er að hér er um faraldsfræðileg gögn að ræða sem geta vanmetið nýgengi kransæðasjúkdóma. Pessu til viðbótar hafa framfarir í læknavísindum leitt til pess að sífellt hærra hlutfall sjúklinga lifir hjartaáföll af og lifir fram á elliár með langvinnum afleiðingum kransæðasjúkdómanna, hjartabilun og hjartsláttartruflunum. Um 80\% allra tilfella kransæðasjúkdóma eru afleiðingar af vel pekktum áhættupáttum sem við getum haft áhrif á með lífsstíl. Pess vegna er mikilvægt að fylgjast náið með próun pessara áhættupátta svo grípa megi inn í pessa próun með markvissum aðgerðum. Par vega pyngst lýðgrunduð inngrip en skimun heilbrigðra einstaklinga á miðjum aldri með næmari greiningaraðferðum, svo sem staðlaðri hálsæðaómun, getur leitt af sér markvissar forvarnaraðgerðir til að bæta lýðheilsu.

\section{Pakkir}

Laufeyju Steingrímsdóttur prófessor í matvæla og næringarfræði er pökkuð sérfræðiráđgjöf, Ólafi B Einarssyni verkefnisstjóra hjá Embætti landlæknis er pakkað fyrir greiðar upplýsingar um notkun statínlyfja á Íslandi. Ragnheiði Brynjólfsdóttur er pökkuð aðstoð við ritvinnslu.

\section{ENGLISH SUMMARY}

\section{Five decades of coronary artery disease in Iceland. Data from the Icelandic Heart Association}

Karl Andersen, ${ }^{1,2,3}$ Thor Aspelund, ${ }^{3}$ Elías Freyr Guðmundsson, ${ }^{1}$ Kristín Siggeirsdóttiri, Rósa Björk Pórólfsdóttir, ${ }^{2}$ Gunnar Sigurðsson,,${ }^{1,2}$ Vilmundur Guð̋nason ${ }^{1}$

Coronary artery disease has been the leading cause of death and disability in Iceland during the past decades although in recent years, malignancy has taken over that position. A steady improvement in the level of major risk factors has been evident since 1980. This trend explains $72 \%$ of the decrease in premature mortality from coronary artery disease during the past three decades. However, an opposing trend in increasing obesity and type 2 diabetes has attenuated this decline in premature deaths. Unchanged risk factor trends will lead to increasing cardiovascular mortality in the years to come. This will result from the above mentioned changes in major risk factors as well as an increased ageing of the Icelandic population. At the same time case fatality after myocardial infarction has declined substantially. This will result in a steadily growing proportion of elderly in the population as well as a high burden of chronic non-communicable diseases among the elderly population. The resulting increase in long term disease and disability will put a major constraint on the health care system and economy alike. According to vital statistics and secular trends the rate of Icelanders in working age for each one reaching retirement age will decrease from the current 5.6 to 2.6 by year 2060. This paper addresses the driving factors of risk factor change in Iceland with previously unpublished data extending to 2013. 


\section{Heimildir}

1. Aspelund T, Gudnason V, Magnusdottir BT, Andersen K, Sigurdsson G, Thorsson B, et al. Analysing the Large Decline in Coronary Heart Disease Mortality in the Icelandic Population Aged 25-74 between the Years 198 and 2006. PLoS One. 2010;5(11):e13957.

2. Thorolfsdottir RB, Aspelund T, Capewell S, Critchley J, Gudnason V, Andersen K. Population assessment of future trajectories in coronary heart disease mortality. PLoS One. 2014;9(1):1-8.

3. Andersen K, Johannesdottir BK, Kristjansson JM, Gudnason $\mathrm{T}$. Decreasing case fatality in myocardial infarction is explained by improved medical treatment. Acta Cardiol. 2011;66(1):39-49.

4. Sigfusson N, Sigurdsson G, Agnarsson U, Gudmundsdotti II, Stefansdottir I, Sigvaldason H, et al. Declining Coronary Heart Disease Mortality in Iceland: Contribution by Incidence, Recurrence and Case Fatality Rate. Scand Cardiovasc J. 2002;36(6):337-41.

5. Sigfusson N, Sigurdsson G, Agnarsson U, Gudmundsdottir II, Stefansdottir I, Sigvaldason $\mathrm{H}$, et al. Breytingar á tíðni kransæðasjúkdóma á Íslandi. Læknablaðið. 2001;87(11):889-96.

6. Andersen K, Gudnason V. Langvinnir sjúkdómar: heimsfaraldur 21. aldar. Læknablaðið. 2012;98(11):591-5.

7. Sigfusson N, Sigvaldason H, Steingrimsdottir L Gudmundsdottir II, Stefansdottir I, Thorsteinsson T, et al. Decline in ischaemic heart disease in Iceland and chang in risk factor levels. BMJ. 1991;302(6789):1371-5.

8. Bjornsson G, Bjornsson OJ, Davidsson D, Kristjansson BTh, Olafsson O, Sigfusson N, et al. Report abc XXIV. Health survey in the Reykjavik area-women. Stage I-III, 1968-1969, 1971-1972 and 1976-1978. Participants, invitation, response etc. The Icelandic Heart Association Reykjavik, Iceland 1982.

9. Bjornsson OJ, Davidsson D, Olafsson $\mathrm{H}$, Olafsson $\mathrm{O}$ Sigfusson N, Thorsteinsson Th. Report XVIII. Health survey in the Reykjavik area-men. Stages I-III, 19671968, 1970-1971 and 1974-1975. Participants, invitation, response etc. The Icelandic Heart Association, Reykjavik, Iceland 1979.

10. Harris $\mathrm{T}$, Launer LJ, Eiriksdottir G, Kjartansson $\mathrm{O}$ Jonsson PV, Sigurdsson G, et al. Age, Gene/Environment Susceptibility-Reykjavik Study: multidisciplinary applied phenomics. Am J Epidemiol 2007;165(9):1076-87

11. Sturlaugsdottir R, Aspelund T, Bjornsdottir G, Sigurdsson S, Thorsson B, Eiriksdottir G, et al. Prevalence and determinants of carotid plaque in the cross-sectional REFINEReykjavik study. BMJ open. 2016:6(11):e012457

12. Mogensen BA, Bjornsson HM, Thorgeirsson G, Haraldsson GE, Mogensen B. Árangur endurlífgunartilrauna utan spítala á Reykjavíkursvæðinu árin 2004-2007. Læknablaðið. 2015;101(3):137-41.

13. www.healthdata.org - júní 2017.

14. Ainsworth JD, Carruthers E, Couch P, Green N O'Flaherty M, Sperrin M, et al. IMPACT: A generic tool for modelling and simulating public health policy. Methods Inf Med. 2011;50(5):454-63.

15. Ford ES, Capewell S. Proportion of the Decline in Cardiovascular Mortality Disease due to Prevention Versus Treatment: Public Health Versus Clinical Care. Annu Rev Public Health. 2011;32(1):5-22.

16. Collaborative Group. Randomised trial of intravenous streptokinase, oral aspirin, both, or neither among 17187 cases of suspected acute myocardial infarction: ISIS-2. Lancet. 1988;2(8607):349-60.

17. Yusuf S, Hawken S, Ounpuu S, Dans T, Avezum A Lanas F, et al. Effect of potentially modifiable risk factors associated with myocardial infarction in 52 countrie (the INTERHEART study): case-control study. Lancet. 2004;364(9438):937-52.

18. The Acute Infarction Ramipril Efficacy (AIRE) Study Investigators. Effect of ramipril on mortality and morbidity of survivors of acute myocardial infarction with clinical evidence of heart failure. Lancet. 1993;342(8875):821-8.

19. Pfeffer MA, Braunwald E, Moye LA, Basta L, Brown EJ Cuddy TE, et al. Effect of Captopril on Mortality and Morbidity in Patients with Left Ventricular Dysfunctio after Myocardial Infarction. Results of the survival and ventricular enlargement trial. The SAVE Investigators. N Engl J Med. 1992;327(10):669-77.
20. Navarese EP, Gurbel PA, Andreotti F, Tantry U, Jeong Y-H, Kozinski M, et al. Optimal Timing of Coronary Invasive Strategy in Non-ST-Segment Elevation Acute Coronary Syndromes: A Systematic Review and Metaanalysis. Ann Intern Med. 2013;158(4):261-70.

21. The RISC Group. Risk of myocardial infarction and death during treatment with low dose aspirin and intravenous heparin in men with unstable coronary artery disease. Lancet. 1990;336(8719):827-30.

22. Hjalmarson A, Goldstein S, Fagerberg B, Wedel $\mathrm{H}_{\text {, }}$ Waagstein F, Kjekshus J, et al. Effects of ControlledRelease Metoprolol on Total Mortality, Hospitalizations, and Well-being in Patients With Heart Failure: the Metoprolol CR/XL Randomized Intervention Trial in congestive heart failure (MERIT-HF). MERIT-HF Study Group. JAMA. 2000;283(10):1295-302.

23. Bangalore S, Pursnani S, Kumar S, Bagos PG. Percutaneous Coronary Intervention Versus Optimal Medical Therapy for Prevention of Spontaneous Myocardial Infarction in Subjects With Stable Ischemic Heart Disease. Circulation. 2013;127(7):769-81

24. Bangalore S, Steg G, Deedwania P, Crowley K, Eagle KA Goto S, et al. Beta-Blocker Use and Clinical Outcomes in Stable Outpatients With and Without Coronary Artery Disease. JAMA. 2012;308(13):1340-9.

25. Scandinavian Simvastatin Survival Study Group. Randomised trial of cholesterol lowering in 4444 patients with coronary heart disease: the Scandinavian Simvastatin Survival Study (4S). Lancet. 1994;344(8934):1383-9.

26. Wallentin LC. Aspirin ( $75 \mathrm{mg} /$ day) after an episode of unstable coronary artery disease: long-term effects on the risk for myocardial infarction, occurrence of severe angina and the need for revascularization. Research Group on Instability in Coronary Artery Disease in Southeast Sweden. J Am Coll Cardiol. 1991;18(7):1587-93.

27. Dominguez-Rodriguez A, Abreu-Gonzalez P, Reiter R. Cardioprotection and pharmacological therapies in acute myocardial infarction: Challenges in the current era. World J Cardiol. 2014:6(3):100-6.

28. Schelbert EB, Cao JJ, Sigurdsson S, Aspelund T, Kellman $\mathrm{P}$, Aletras $\mathrm{AH}$, et al. Prevalence and Prognosis of Unrecognized Myocardial Infarction Determined by Cardiac Magnetic Resonance in Older Adults. JAMA. 2012;308(9):890-6.

29 Steingrimsdottir L, Valgeirsdottir $\mathrm{H}$, Halldorsson $\mathrm{T}$, Gunnarsdottir I, Gisladottir E, et al. Kannanir á mataræði og næringargildi fæðunnar á Íslandi. Læknablaðið. 2014;100(12):659-64.

30. Nordic Council of Ministers. Nordic Nutrition Recommendations 2012: Integrating nutrition and physical activity. $5^{\text {th }}$ ed. Nordic Nutrition Recommendations 2012, Denmark 2014.

31. Embætti Landlæknis. Ráðleggingar um mataræði fyrir fullorðna og börn frá tveggja ára aldri. Embætti Landlæknis, Reykjavik 2016.

32. Matthiessen J, Andersen L, Barbieri $\mathrm{H}$, Borodulin $\mathrm{K}$ Knudsen V, Korup K, et al. The Nordic Monitoring System 2011-2014: Status and development of diet, physical activity, smoking, alcohol and overweight. Nordic Council o Ministers, Denmark 2016

33. Thorsson B, Steingrimsdottir L, Halldorsdottir S, Andersen K, Sigurdsson G, Aspelund T, et al. Changes in total cholesterol levels in Western societies are not related to statin, but rather dietary factors: the example of the Icelandic population. Eur Heart J. 2013;34(24):1778-82.

34. Jonsdottir L, Jensson V. Próun tóbaksneyslu á Íslandi Embætti landlæknis, Reykjavik 2016.

35. Sigfusson N, Sigurdsson G, Sigvaldason H, Gudnason V. Breytingar á reykingavenjum miðaldra og eldri Íslendinga síðastliðin prjátíu ár og ástæður peirra. Niðurstöður úr hóprannsóknum Hjartaverndar. Læknablaðið. 2003;89(6):489-98.

36. Sigfusson N, Sigurdsson G, Aspelund T, Gudnason V. Skaðleg áhrif reykinga á heilsufar hafa verið verulega vanmetin - Niðurstöður úr hóprannsóknum Hjartaverndar. Læknablaðið. 2006:92(4):263-9.

37. Farber H, Walley S, Groner J, Nelson K. Clinical Practice Policy to Protect Children From Tobacco, Nicotine, and Tobacco Smoke. Pediatrics. 2015;136(5):1008-17.
38. Dinakar C, O'Connor GT. The Health Effects of Electronic Cigarettes. N Engl J Med. 2016;375(14):1372-81.

39. Beaglehole R, Bonita R, Yach D, Mackay J, Reddy KS. A tobacco-free world: a call to action to phase out the sale of tobacco products by 2040. Lancet. 2015;385(9972):1011-8.

40. Chobanian A, Bakris G, Black H, Cushman W, Green L, Izzo JLJ, et al. The Seventh Report of the Joint National Committee on Prevention, Detection, Evaluation, and Treatment of High Blood Pressure.The JNC 7 Report. JAMA. 2003;289(19):2560-72

41. Mozaffarian D, Fahimi S, Singh GM, Micha R, Khatibzadeh $\mathrm{S}$, Engell RE, et al. Global Sodium Consumption and Death from Cardiovascular Causes. N Engl J Med 2014;371(7):624-34

42. Powles J, Fahimi S, Micha R, Khatibzadeh S, Shi P, Ezzati $\mathrm{M}$, et al. Global, regional and national sodium intakes in 1990 and 2010: a systematic analysis of $24 \mathrm{~h}$ urinary sodium excretion and dietary surveys worldwide. BMJ Open. 2013;3(12):e003733.

43. Gudnason V, Sigfusson N, Sigurdsson G. Læknablaðið 100 ára. Rannsóknarstöð Hjartaverndar, fortíð og nútíð. Læknablaðið. 2014;100(9):456-64.

44. Kotseva K, De Bacquer D, De Backer G, Ryden L, Jennings C, Gyberg V, et al. Lifestyle and risk factor management in people at high risk of cardiovascular disease. A report from the European Society of Cardiology European Action on Secondary and Primary Prevention by Intervention to Reduce Events (EUROASPIRE) IV cross-sectional survey in 14 European regions. Eur J Prev Cardiol. 2016:23(18):2007-18.

45. Masters R, Anwar E, Collins B, Cookson R, Capewel S. Return on investment of public health interventions a systematic review. J Epidemiol Community Health. 2017;jech-2016.

46. OECD/EU. Health at a Glance: Europe 2016-State of Health in EU Cycle. OECD Publishing, Paris 2016.

47. The Emerging Risk Factors Collaboration. Diabetes Mellitus, Fasting Glucose, and Risk of Cause-Specific Death. N Engl J Med. 2011;364(9):829-41.

48. Thrainsdottir IS, Aspelund T, Gudnason V, Malmberg K, Sigurdsson G, Thorgeirsson G, et al. Increasing glucose levels and BMI predict future heart failure. Experience from the Reykjavik Study. Eur J Heart Fail. 2007:9(10):1051-7.

49. Olafsdottir E, Aspelund T, Sigurdsson G, Thorsson B, Eiriksdottir G, Harris TB, et al. Effects of statin medication on mortality risk associated with type 2 diabetes in olde persons: the population-based AGES-Reykjavik Study. BMJ Open. 2011;1(1):e000132-e000132.

50. Dehghan M, Mente A, Zhang X, Swaminathan S, Li W, Mohan V, et al. Associations of fats and carbohydrate intake with cardiovascular disease and mortality in 18 countries from five continents (PURE): a prospective cohort study. The Lancet. 2017 Aug 29

51. Andersen K, Gudnason V. Stefnumörkun í heilbrigðismálum: leiðin til lýðheilsu. Læknablaðið. 2013;99(3):129-34.

52. Danielsen R, Thorgeirsson G, Einarsson H, Olafsson O, Aspelund T, Harris TB, et al. Prevalence of heart failure in the elderly and future projections: the AGES-Reykjavik study. Scand Cardiovasc J. 2017;51(4):183-9.

53. Sturlaugsdottir R, Aspelund T, Bjornsdottir G, Sigurdsson $\mathrm{S}$, Thorsson B, Eiriksdottir $\mathrm{G}$, et al. Prevalence and determinants of carotid plaque in the cross-sectional REFINEReykjavik study. BMJ Open. 2016;6(11):e012457.

54. Rasmussen LB, Andersen LF, Borodulin K, Barbieri HE Fagt S, Matthiessen J, et al. Nordic monitoring of diet, physical activity and overweight. Nordic Council of Ministers, Denmark 2012

55. Rose G. Sick individuals and sick populations. Int J Epidemiol. 2001;30(3):427-32 